have been buried purposely, has been found in a brick enclosure to the east of the Math. Among this pottery one type has a series of spouts, in number from four to thirty-four and of various designs. Most of the vessels bear representations of snakehoods. This fact is taken as a confirmation of the theory that the site was sacred to the worship of the Nagas or snake-goddesses. Pottery with multiple spouts is not known from other sites in India. The popular name of Maniyar Math, it is thought, may preserve a tradition of Mant Naga, the preserver and rain-giver of Rajagriha. If this indeed be so, it is suggested that these vessels with their multiple channels were the votive offerings of suppliants for rain, which were deposited in the compound of the shrine. Serpent worship at Raigir can be traced back to the third century B.c. and still persists as a popular cult. In the course of excavations carried out on behalf of the Raffles Museum, Singapore, on the Phinsoon Estate at Sungei Siput, Malacca, Prof. Van Stein Callenfels, the distinguished authority on the archæology of the Malayan archipelago, it is reported by Reuter, has discovered a number of human skeletons believed to date from about 2,500 B.c.

\section{The Approach to the Absolute Zero}

ThE Science Museum, South Kensington, has recently performed a most useful public service in arranging, in connexion with the Very Low Tem. peratures Exhibition, for a series of demonstrations and lectures by eminent authorities on recent scientific and technical developments. The series was concluded on Wednesday, May 27, by Prof. F. Simon, late of Berlin and Breslau and now of the Clarendon Laboratory, Oxford. Of the problems which can be investigated by experiment in the new temperature region below $1^{\circ}$ Absolute, one of the most interesting is the specific heat of paramagnetic salts. In experiments carried out in conjunction with Kürti, Rollin and Lainé with the huge electromagnet of the Paris Academy of Sciences, it has been proved that the paramagnetic salts used become ferromagnetic at very low temperatures, showing Curie points of about $0 \cdot 01^{\circ}$ Absolute (see p. 961). The small helium liquefier used in the experiments was transported from Oxford. At the Science Museum, Prof. Simon succeeded in demonstrating a temperature of $0.12^{\circ}$ Absolute, a noteworthy achievement, of which Prof. Simon and his co-workers, Mr. G. L. Pickard and Mr. A. H. Cooke, who were responsible for erecting the apparatus in the Science Museum and for the fact that the demonstration went off without a hitch, may well be proud. The magnet used in the experiment was lent by the Imperial College of Science and Technology; the hydrogen and helium pumps by Messrs. W. Edwards and Co.; the Cambridge Instrument Co., Ltd., provided a galvanometer. The limiting temperature region for this method lies between $0.01^{\circ}$ and $0.001^{\circ}$ Absolute. Further reduction of temperature will depend on the use of nuclear paramagnetism, starting at about $0.01^{\circ}$ Absolute. Even to this method there will be a temperature limit, and the distance from the absolute zero, although very small when measured in degrees, is in reality an infinity. Although this unique series of lectures has now come to an end, the Exhibition of Very Low Temperatures will continue until the end of June. The Exhibition has so far attracted more than 140,000 visitors, and interest in it has not in any way diminished during the three months in which it has been on view.

\section{Maiden Voyage of the Queen Mary}

Britain's newest and finest liner, the Queen Mary, left Southampton Docks on Wednesday, May 27, and entered New York Harbour about four and a half days later after successfully completing her maiden trans-Atlantic trip. Whatever may have been the results of this crossing from the point of view of marine navigation, a new standard was set up in radio communication by the most successful completion of a series of daily broadcasting programmes throughout the voyage. Never before has the whole world been able to follow so closely the daily happenings on board an ocean liner. The progress made in this application of the art of radio communication is illustrated by a note from a special correspondent of The Times, who recalled that he was one of the only two journalists on board the Mauretania on her maiden voyage to New York nearly thirty years ago: his instructions were to send not more than twelve words a day by wireless, and to post an article from New York. In contrast with this, the Queen Mary carried about 150 journalists, and some twenty broadcast commentators of various nationalities. During the voyage, more than sixteen hours actual broadcasting took place from the ship, while many hundreds of wireless messages of all kinds were sent to all parts of the world. To enable this work to be carried out, the normal wireless installation in the Queen Mary (which was referred to in NATURE of January 18 last) was supplemented by special equipment fitted by the British Broadcasting Corporation. More than twenty microphones were fitted in various parts of the ship so that the general life on board could be described direct from the scene of activity in the course of the daily broadcasting programme. Each evening, listeners to British stations were provided with an interesting commentary direct from the Queen Mary, while on one afternoon a special programme was arranged for schoolchildren.

These broadcasts were received in Great Britain via the ship-to-shore radio-telephone service of the Post Office; they were naturally relayed through the Empire system, and the high standard of performance attained is greatly to the credit of all those concerned with the arrangements. Similar programmes were arranged by the appropriate authorities for listeners in America, Denmark, France and Holland. The climax of this radio sound-picture was provided by the joint programme arranged by the B.B.C. and the National Broadcasting Company of America, as the Queen Mary proceeded up the 